A systematic review

\title{
Is placing a victim in the left lateral decubitus position an effective first aid intervention for acute oral poisoning?
}

Vere Borra ${ }^{1}$, Bert Avau ${ }^{1,2}$, Peter De Paepe ${ }^{3}$, Philippe Vandekerckhove ${ }^{4,5}$ Emmy De Buck $^{1,4}$

${ }^{1}$ Centre for Evidence-Based Practice, Belgian Red Cross, Mechelen, Belgium;

${ }^{2}$ Cochrane Belgium, Center for Evidence-Based Medicine (Cebam), Leuven, Belgium;

${ }^{3}$ Department of Emergency Medicine, Ghent University Hospital, Ghent, Belgium;

${ }^{4}$ Department of Public Health and Primary Care, Faculty of Medicine, KU Leuven, Leuven, Belgium;

${ }^{5}$ Belgian Red Cross, Mechelen, Belgium.

Contact information:

Bert Avau

Motstraat 42

2800 Mechelen

Belgium

bert.avau@cebap.org

\section{Funding and disclosure}

This work is supported by the Foundation for Scientific Research of the Belgian Red Cross. The funder had no role in the design or conduct of this work.

VB, BA, ED and PV are employees of the Belgian Red Cross. PDP is emergency physician and clinical pharmacologist at the Ghent University Hospital and Ghent University (Belgium). The authors have nothing to disclose.

Word count: 3437 (without abstract)

Number of figures: 3

Number of tables: 3 


\section{Abstract}

Introduction: In acute oral poisoning, any first aid intervention that limits or delays the uptake of the ingested substance, and which can be performed by bystanders as first responders, might assist in reducing morbidity if a toxic substance has been ingested. The current recommendation by the International Federation of Red Cross/Red Crescent Societies is to place a victim in the left lateral decubitus position.

Objective: The aim of this PRISMA compliant systematic review is to assess whether the current recommendation by the International Federation of Red Cross/Red Crescent Societies decreases or delays the absorption of an orally ingested poison.

Methods: The Cochrane Library, MEDLINE, Embase, CINAHL and ISI Web of Science were searched in April 2018 for (quasi) randomized controlled trials investigating different body positions that are feasible in a pre-hospital setting by non-healthcare professionals. Data concerning study identification, study design, population, intervention and comparison, outcome measures and study quality were independently extracted and tabulated from the included studies by two reviewers, using a standardized and piloted data extraction form. The same two authors assessed the risk of bias in the included studies independently, using Cochrane's tool for assessing risk of bias. The GRADE approach was used to judge the certainty of evidence.

Results: A total of 4,991 citations were identified. After removal of 1,313 duplicates, the titles and abstracts of 3,678 references were screened using the predefined selection criteria. This screening yielded 35 potentially relevant articles which were assessed for eligibility using their full text. Twenty-four papers were excluded as they did not meet the selection criteria; 9 studies reported in 10 papers were included with a total of 72 participants. All selected studies were performed in a controlled setting using healthy volunteers in a cross-over design. No studies involved poisoned patients. In four studies, the participants ingested paracetamol as a test drug. In the 5 other studies, the following pharmaceuticals were ingested: sodium salicylate, midazolam, nifedipine combined with paracetamol, amoxicillin or slow release theophylline. Drugs were ingested after a period of fasting which varied between $2 \mathrm{~h}$ and $9 \mathrm{~h}$. Different body positions were tested: left lateral position, right lateral position, bed rest during the day, supine position, prone position or upright position, 
standing or remaining ambulatory. In two studies, it was shown that the left lateral position (with or without $20 \%$ head down tilt) resulted in a statistically significant decrease of paracetamol AUC and $\mathrm{C}_{\max }$ compared to the right lateral position (with or without $20 \%$ head up tilt), sitting and prone position. In two further studies, a statistically significant difference in paracetamol AUC and $\mathrm{C}_{\max }$ between bed rest or the left lateral position and ambulation could not be demonstrated. In another study it was shown that lying on the left side resulted in a statistically significant decrease of nifedipine and its nitropyridine metabolite $A \cup C$ and $C_{\max }$, and a statistically significant increase of paracetamol, nifedipine and nitropyridine metabolite $\mathrm{T}_{\max }$ compared to lying on the right side or standing. One study looked at the effect of remaining strictly supine compared to remaining ambulant on the uptake of oral midazolam $15 \mathrm{mg}$. It was shown that remaining strictly supine resulted in a statistically significant decrease of $\mathrm{C}_{\max }$ compared to remaining ambulant. Overall, evidence was of very low certainty due to limitations in study design, imprecision due to limited sample size and lack of data, and indirectness.

Conclusions: The identified studies provide evidence of very low certainty. However, based on the evidence that the left lateral decubitus position may be effective in decreasing the absorption of several drugs, the simplicity of the intervention and the generally low perceived risk of this intervention, the recommendation of the first aid guidelines of the International Federation of Red Cross and Red Crescent Societies can remain unchanged.

\section{Keywords:}

Poisoning; Body position; First Aid; Laypeople; Drug absorption; Drug overdose 


\section{Introduction}

Poisoning is a common cause of morbidity and mortality worldwide [1]. In acute oral poisoning, any first aid intervention that limits or delays the uptake of the ingested substance, and which can be performed by bystanders as first responders, might assist in reducing morbidity if a toxic substance has been ingested. The current recommendation, made in 2016 by the International Federation of Red Cross/Red Crescent Societies (IFRC) is to place a victim in the left lateral decubitus position [2].

\section{Objective}

The aim of this PRISMA (Preferred Reporting Items in Systematic Reviews and Meta-analyses) compliant systematic review is to assess whether the current recommendation by the IFRC is appropriate. Therefore, the following PICO (populationintervention-comparison-outcome) question was formulated: In humans with acute oral poisoning $(P)$, is a certain body position $(I)$ compared to another body position or no intervention (C) effective as a first aid treatment to limit or delay absorption of the poison in the body $(\mathrm{O})$ ? This helps to precisely frame a research question, and allows to structure the literature search, study selection and data-analysis.

\section{Methods}

This systematic review was planned and reported according to the Preferred Reporting Items for Systematic Reviews and Meta-Analyses (PRISMA) checklist (Appendix 1), a reporting checklist to verify whether all important aspects of systematic reviews and meta-analyses are reported in a publication [3]. A protocol for first aid for poisoning is registered in PROSPERO (prospective register of systematic reviews:

http://www.crd.york.ac.uk/PROSPERO/display record.php?ID=CRD42017065911). This protocol was intended for a broader review question, including all possible interventions (i.e. activated charcoal, cathartics, emetics, etc.) and all possible study populations (i.e. poisoning patients as well as healthy volunteers). After an initial search, many studies in poisoning patients were identified, which led to the decision to limit the review to this study population. This review has been submitted with the Cochrane collaboration. Since no evidence in poisoning patients was available for body positioning, we expanded the population for this systematic review to include healthy volunteers as well. The initial search was outdated, so we performed a new 
search for body positioning alone, using the methods described further on the 'Search methods' section.

\section{Selection criteria}

The components of the PICO question were used to define selection criteria for including potentially relevant studies. The following in- and exclusion criteria were considered in selecting studies:

Population: We considered studies which investigated patients poisoned via oral ingestion, both deliberate and accidental. In addition to studies in a community setting, studies conducted in a healthcare setting were also considered. Furthermore, studies in healthy volunteers with a simulated overdose were also within scope of this review.

Intervention: The interventions within the scope of this systematic review were any type of body position.

Comparison: We wanted to compare a certain body position either to another body position or to no intervention.

Outcome: Possible outcomes of interest for this systematic review were mortality, adverse events due to the intervention, incidence and severity of features of poisoning, duration of toxic features, drug absorption, measured as maximum drug concentration in the blood $\left(\mathrm{C}_{\max }\right)$, time to $\mathrm{C}_{\max }\left(\mathrm{t}_{\max }\right)$ or area under the curve (AUC) of drug concentration versus time, incidence and duration of hospitalization and incidence and duration of ICU admission. However, the actual reporting of outcomes of interest as such was not considered a selection criterion, which means studies with an appropriate study design, population and intervention were included in the review and described narratively.

Study design: We looked for (quasi) randomized trials, with or without a cross-over design. Observational studies, such as cross-sectional (case-control) studies or cohort studies, letters, comments, narrative reviews, case reports, or animal studies were excluded. Conference abstracts without useable data were also excluded. There were no language restrictions. 


\section{Search methods}

The following databases were searched from date of inception until 5 April 2018: the Cochrane library, Medline (using the PubMed interface), Embase (using the Embase.com interface), CINAHL (using EBSCO host) and ISI Web of Science. For each database, we looked specifically for studies on body positioning by combining search terms such as "poisoning", "poison", "toxic ingestion", "intoxication", "overdose", "absorption", "pharmacokinetics", "gastrointestinal motility" or "gastric emptying" with search terms such as "left side", "body position", "posture" or "lateral decubitus". Full search strategies for all databases can be found in Appendix 2. For each included study, reference lists and the first twenty "similar articles" in PubMed were also screened for additional relevant records.

\section{Study Selection}

After removing 1,313 duplicates, references were screened based on title and abstract by two reviewers (VB and BA) independently. Subsequently, full texts were retrieved and assessed for eligibility to the predefined selection criteria, using a piloted study selection form. Discrepancies between both reviewers were discussed and if no consensus could be reached, a third reviewer (EDB) was consulted.

\section{Data extraction and quality assessment}

Data concerning study identification, study design, population, intervention and comparison, outcome measures and study quality were independently extracted and tabulated from the included studies by two reviewers (VB and BA), using a standardized and piloted data extraction form. Data were expressed as mean difference (MD) with a 95\% confidence interval $(\mathrm{Cl})$ in case of continuous outcomes, or odds ratios $(\mathrm{OR})$ or risk ratios $(\mathrm{RR})$ with a $95 \% \mathrm{Cl}$ in case of dichotomous outcomes, if available. If possible, effect measures were calculated from the raw data using Review Manager 5 software [4]. Outcomes without raw data or statement of significance were not extracted from the studies. In case of missing data, attempts were made to retrieve them from study authors, if contact details were available.

Two authors (VB and BA) assessed the risk of bias in the included studies independently, using Cochrane's tool for assessing risk of bias [5]. The domains that were assessed are sequence generation, allocation concealment, blinding of participants and personnel, blinding of outcome assessment, incomplete outcome data 
addressed, selective reporting and possible other bias. Each domain was rated as having a low, high or unclear risk of bias.

The certainty of the body of evidence from the included studies for each outcome was assessed according to the GRADE approach [6]. This approach assesses the certainty of evidence for separate outcomes across the different studies in 5 domains: limitations in study design (as described above), consistency, imprecision, indirectness and publication bias. Randomized controlled trials start with a high certainty of evidence, which can be downgraded by 1 (serious limitations) or 2 (very serious limitations) points for each of these domains. The certainty of evidence can therefore be high, moderate, low or very low. We decided to downgrade for limitations in study design for an outcome if at least one study contributing to the outcome was judged to have a high risk of bias in one of following crucial bias domains: selection bias, detection bias, attrition bias or other bias. We decided not to take into account domains with unclear risk of bias.

\section{Results}

\section{Results of the search}

A total of 4,991 references were identified using the search strategy in Appendix 2 . After removal of 1,313 duplicates, the titles and abstracts of 3,678 references were screened using the predefined selection criteria. This screening yielded 35 potentially relevant articles which were assessed for eligibility using their full text. Twentyfour papers were excluded (Table 1) as they did not meet the selection criteria [730], leaving 10 references, reporting 9 studies [31-40]. All selected studies were performed in a controlled setting using healthy volunteers in a cross-over design. No studies involved poisoned patients. A flowchart of the study identification can be found in Figure 1.

\section{Study Characteristics}

All identified studies were randomized cross-over trials, with all volunteers participating in all phases. A total of 72 volunteers were included. In four studies, the participants ingested paracetamol as a test drug [31-34]. In the 5 other studies, the following pharmaceuticals were ingested: sodium salicylate [35], midazolam [36], nifedipine combined with paracetamol [37], amoxicillin [38] or slow release 
theophylline [39]. Drugs were ingested after a period of fasting which varied between $2 \mathrm{~h}$ and $9 \mathrm{~h}$. Different body positions were tested: left lateral position (all the time, for the first two hours followed by being ambulatory or with a $20^{\circ}$ head down tilt), right lateral position (with or without a $20^{\circ}$ head up tilt), bed rest during the day, supine position, prone position or upright position, standing or remaining ambulatory. The positions were kept over a period ranging from 1 to 7 hours after drug intake, however the duration of the intervention was not mentioned in several papers. An overview of all study characteristics can be found in Table 2 .

\section{Synthesis of findings}

Due to a lack of data, a meta-analysis could not be performed. An overview of study findings can be found in Table 3, and results are narratively explained below. In four studies, the effect of a certain body position on the pharmacokinetics of paracetamol was studied [31-34]. In two studies, it was shown that the left lateral position (with or without $20 \%$ head down tilt) resulted in a statistically significant decrease of AUC and $\mathrm{C}_{\max }$ compared to right lateral position (with or without $20 \%$ head up tilt), sitting and prone position [33,34]. One of these studies also found that the supine position resulted in a statistically significant decrease of AUC compared to the sitting and prone position [33].

Additionally, in two studies, a statistically significant difference in AUC and $\mathrm{C}_{\max }$ between bed rest or the left lateral position and ambulation could not be demonstrated [31, 32].

Two studies reported the $T_{\max }$ of paracetamol and/or its glucuronide and sulphate metabolites in response to bed rest or the left lateral position with $20 \%$ head down tilt, compared to ambulation or the right lateral position with $20 \%$ head up tilt, respectively $[32,34]$ No difference in $T_{\max }$ could be demonstrated between different body positions.

One study reported that no adverse events (nausea, vomiting, pruritus) occurred in response to paracetamol ingestion followed by different body positions [34]. One study investigated the effect of bed rest compared to ambulation on amoxicillin pharmacokinetics. No statistically significant difference could be demonstrated for $\mathrm{C}_{\max }$ and $\mathrm{T}_{\max }$ when comparing both body positions [38].

One study investigated the effect of a left lateral position compared to remaining ambulant on the pharmacokinetics of crystalline sodium salicylate. It was shown 
that remaining ambulatory resulted in a statistically significant decrease of cumulative urinary excretion of salicyluric acid after $2 \mathrm{~h}$ and $4 \mathrm{~h}$ [35].

One study looked at the effect of remaining strictly supine compared to remaining ambulant on the uptake of oral midazolam $15 \mathrm{mg}$. It was shown that remaining strictly supine resulted in a statistically significant decrease of $\mathrm{C}_{\max }$ compared to remaining ambulant. However, a statistically significant difference in $T_{\max }$ between remaining strictly supine or ambulant could not be demonstrated [36].

In one study, the effect of lying on the left or the right side was compared to standing on the pharmacokinetics of paracetamol and nifedipine after ingesting nifedipine $2 \times 10 \mathrm{mg}$ combined with soluble paracetamol $1 \mathrm{~g}$ [37]. The study showed evidence in favour of the recumbent left position. It was shown that lying on the left side resulted in a statistically significant decrease in the $\mathrm{C}_{\max }$ and $A U C$ of nifedipine and its nitropyridine metabolite, and a statistically significant increase in the $T_{\max }$ of paracetamol, nifedipine and nitropyridine metabolite compared to lying on the right side or standing. Furthermore, when comparing lying on the right side with standing, it was shown that lying on the right side resulted in a statistically significant decrease in the $\mathrm{C}_{\max }$ of nifedipine and nitropyridine metabolite and a statistically significant increase in the $T_{\max }$ of nifedipine and nitropyridine metabolite when compared to standing. A statistically significant difference in paracetamol $C_{\max }$ and $A U C$ could not be demonstrated when lying on the left side, the right side or standing. Finally, a statistically significant difference in pulse rate, but not diastolic blood pressure was shown when comparing the left lateral to the right lateral position.

Finally, one study compared the supine position with remaining standing on theophylline plasma concentrations after the ingestion of slow release theophylline $450 \mathrm{mg}$. No statements of significance were made for pharmacokinetic parameters. Furthermore, no adverse events were reported for both body positions [39].

\section{Risk of bias}

Figures 2 and 3 provide an overview of the risk of bias across domains and studies. Three studies were at high risk of selection bias, because it was not mentioned whether the order of treatments was randomized and how randomization or allocation concealment was done [31, 32, 38]. The remaining 6 studies had an unclear risk of selection bias [33-35, 37, 39]. These studies mentioned that randomization was 
done, but no further information was given on the process of randomization and allocation concealment.

There was a low risk of performance bias in 6 studies [31, 32, 35, 36, 38]. No information was provided on whether blinding was attempted, however, the nature of the interventions, i.e. different body positions, makes blinding of participants and personnel unlikely. This should however not have an influence on pharmacokinetic outcomes. On the other hand, it might influence subjective outcomes such as adverse events, which is why in 3 studies we indicated an unclear risk of performance bias [34, 37, 39].

Seven out of 9 studies had a low risk of detection bias [31-33, 35-38]. There was no information on blinding of outcome assessors but in most cases this should not have influenced the outcomes. In 2 studies, adverse events were also measured, and a lack of blinding might influence the judgment of the outcome assessors [34, 39].

In 8 studies, there was no indication of missing outcome data, leading to a low risk of attrition bias [31-34, 36-39]. One study was judged to have a high risk of attrition bias, since one out of 6 participants did not complete all phases, which led to a drop-out rate of $17 \%$ [35].

There is a high risk of reporting bias in all studies, since there are missing outcomes in all studies. Only 3 studies reported some adverse events, and most studies reported important pharmacokinetic outcomes such as $\mathrm{C}_{\max }, \mathrm{T}_{\max }$ and $\mathrm{AUC}$ only partially or incompletely.

Three studies had other bias such as a short follow-up time and indirect methods for measuring drug concentrations [33, 38, 39].

Based on the risk of bias assessment of the individual studies, the overall certainty level of the evidence was downgraded one level for limitations in study design for all outcomes. We further downgraded one level for imprecision, due to the limited sample size and lack of data available to calculate 95\% confidence intervals of the effect sizes. We finally downgraded one more level for indirectness, due to the volunteer setting of the identified studies. The healthy volunteer setting can be considered a source of indirectness for the patient setting, due to its highly controlled nature. The doses of drugs ingested were in the therapeutic and supratherapeutic, but not in the toxic range, there was no co-ingestion of other substances such as 
alcohol, which is often the case in poisoning patients, and participants fasted between 2 and 9 hours prior to the study, which could have influenced the results. Altogether, we consider this evidence for all outcomes to be of very low certainty, which means that any effect estimate is uncertain [6].

\section{Discussion}

The aim of this review was to assess the effectiveness of body position as first aid treatment for acute oral poisoning. Out of 4991 references, 9 studies from 10 publications were selected. No studies in oral poisoning patients could be identified. All identified studies were cross-over studies performed in healthy volunteers who tested different body positions after intake of paracetamol, nifedipine combined with paracetamol, sodium salicylate, midazolam, amoxicillin or slow release theophylline.

Five studies looked at the effect of certain body positions on the uptake of paracetamol. Results showed that the left lateral position and the supine position may delay the absorption of paracetamol, although not all studies came to this conclusion. Differences between studies may be explained by the dose (ranging from $500 \mathrm{mg}$ to $80 \mathrm{mg} / \mathrm{kg}$ ) and formulation (soluble vs tablets) of the paracetamol ingested and slight differences in the interventions applied (left lateral position with or without $20^{\circ}$ head down tilt).

In one study, it was shown that the left lateral position may delay the absorption of nifedipine [37].

After ingestion of midazolam, the supine position is favoured over remaining ambulatory or sitting [36]. This also makes sense from a practical point of view, due to the possible risk of known side effects such as vertigo and dizziness after intake of midazolam [41]. The left lateral position was not tested in this study.

On the other hand, in case of ingestion of sodium salicylate, remaining ambulatory resulted in a decreased urinary excretion of salicyluric acid, compared to the left lateral position. This is likely due to an increased gastric retention when in the left lateral position, and the fact that, in contrast to other drugs tested, sodium salicylate is effectively absorbed from the stomach $[42,43]$.

As for amoxicillin and slow-release theophylline, no difference could be demonstrated between the tested positions [38, 39]. 
Despite the fact that no statistically significant difference could be demonstrated between the left lateral decubitus and supine positions concerning the absorption of paracetamol, the left lateral decubitus position has a theoretical rationale, which the supine position lacks. Due to the anatomy of the stomach, the left lateral decubitus position would slow down the emptying of the stomach into the small intestine [44-46]. The small intestine is the primary site of absorption for most pharmacological substances. Thus, delaying the gastric emptying into the small intestine decreases the rate of absorption and will therefore limit the potential toxic effects of the ingested drug. Another theoretical advantage of placing and transporting the patient in the left lateral decubitus position instead of the supine position, is that it facilitates patient observation and oropharyngeal drainage, and it helps prevent aspiration in case of emesis [33].

This review has several limitations. Follow-up times ranged from one to 7 hours after intake of the drugs, but in most cases this should be sufficient to get professional help. A different consideration is that the body positions were tested immediately after ingestion of the drug. It is therefore not known what the effect of placing the poisoned patient in the left lateral decubitus or supine position would be if the overdose patient is found several hours after drug ingestion.

Another limitation of the identified studies is that subjects fasted for 2 to 9 hours prior to the intake of the drugs. It is thus not known what the influence would be of food in the stomach. Also, in cases of intentional overdose, drugs are often taken with a certain amount of alcohol and/or other substances, which might also influence the gastric emptying or uptake of the drugs.

Thirdly, all but one of the studies identified in this systematic review investigated the effects of body positioning on the uptake of xenobiotics that were ingested in their solid form. The sole exception is the study by Renwick et al.[37], who administered paracetamol in its soluble form, together with nifedipine in solid form. Perhaps not coincidently, this study demonstrated a statistically significant decrease in uptake of nipedipine, but not of paracetamol. This suggests that the conclusions that can be drawn from this review may be less applicable to liquid ingestions.

Finally, all studies were performed in healthy volunteers in a controlled setting, leading to indirect evidence. Only one of the studies identified had the goal of actually mimicking an acute oral overdose, by using a large number of children's tablets [33] Nevertheless, the doses of drugs used were within therapeutic to supratherapeutic 
ranges in all included studies. No studies were identified in actual oral poisoning patients.

As the identified studies were conducted in healthy volunteers, only data on the pharmacokinetics of the drugs were available. Theoretically, a decrease in gastric emptying rate of an ingested xenobiotic should result in a lower $\mathrm{C}_{\max }$ and $\mathrm{a}$ delayed $T_{\max }$. This would lead to a delay in critical xenobiotic concentrations in the blood, therefore buying more time to get to the hospital for adequate treatment. No evidence could be identified on the actual patient-important outcomes that were prespecified in our protocol, such as mortality, severity and duration of features of poisoning, incidence and length of hospitalization or ICU admission. The sole exception is the study by Renwick et al. [37] who reported blood pressure and pulse rate, which may be considered a 'feature'. This lack of reported patient-important outcomes is also a limitation of this systematic review.

Future studies investigating the potential of adapting the patient's body position as a first aid measure for acute oral poisoning should be conducted in actual poisoning patients. The main issue in these studies will be that the precise ingested dose is not known in actual poisoning patients, which will make it impossible to calculate pharmacokinetic parameters. However, clinical outcomes such as mortality, adverse events due to the intervention, incidence and severity of features of poisoning or duration of toxic features will give more valuable information on the effectiveness of the intervention.

\section{Conclusions}

In conclusion, the identified evidence is scarce and of very low certainty, which means we cannot confidently answer our predefined PICO question and state that one body position is better than another to limit the uptake of ingested xenobiotics. This precludes making strong recommendations for practice. However, based on the evidence that the left lateral decubitus position may be effective in decreasing the absorption of several drugs, the simplicity of the intervention and the generally low perceived risk of this intervention, the recommendation [2] of the first aid guidelines of the International Federation of Red Cross and Red Crescent Societies to place a suspected patient with acute oral poisoning in the left lateral decubitus position until professional help arrives, can remain unchanged. 



\section{References}

[1] World Health Statistics 2016: Monitoring health for the SDGs, sustainable development goals. Geneva, Switzerland: World Health Organization; 2016.

[2] International first aid and resuscitation guidelines 2016 [Internet]. Geneva, Switzerland: International Federation of Red Cross and Red Crescent Societies (IFRC); 2016 [cited 2018 Sept 10]. Available from: http://www.ifrc.org/Global/Publications/Health/First-Aid-2016Guidelines_EN.pdf.

[3] Moher D, Liberati A, Tetzlaff J, et al. Preferred Reporting Items for Systematic Reviews and Meta-Analyses: The Prisma Statement. PLoS Med. 2009; 7:e1000097.

[4] Review Manager (Revman) [Computer program]. Version 5.3. Copenhagen: The Cochrane collaboration; 2014. Online software program, available from https://community.cochrane.org/help/tools-and-software/revman-5.

[5] Higgins JP, Altman DG, Gotzsche PC, et al. The Cochrane Collaboration's Tool for Assessing Risk of Bias in Randomised Trials. BMJ. 2011:d5928.

[6] Atkins D, Best D, Briss PA, et al. Grading Quality of Evidence and Strength of Recommendations. BMJ. 2004;7454:1490.

[7] Appadu BLM, M.C.; Allott, J.; Hampton, H.; Rowbotham, D.J. The Effect of Posture on Gastric Emptying. International Journal of Obstetric Anesthesia 1995;1:67.

[8] Arena JM. Poisoning - Treatment and Prevention. Part I. JAMA. 1975;12:358363.

[9] Arena JM. Poisoning--General Treatment and Prevention. Part li. Jama. 1975;4:358-363.

[10] Backon J, Hoffman A. The Lateral Decubitus Position May Affect Gastric Emptying through an Autonomic Mechanism: The Skin Pressure-Vegetative Reflex. Br J Clin Pharmacol. 1991;1:138-139.

[11] Bani MC, A.; Guillaume, M.; Macchi, F.; Persiani, S.; Moroni, G. A DoubleBlind, Placebo-Controlled Study to Access Tolerability, Pharmacokinetics and Preliminary Pharmacodynamics of Single Escalating Doses of Z13752a, a Novel Dual Inhibitor of the Metalloproteases Ace and Nep, in Healthy Volunteers. British Journal of Clinical Pharmacology 2000;4:338-349.

[12] Channer KS, Dent M, Roberts CJ. The Effect of Posture at the Time of Administration on the Central Depressant Effects of the New Hypnotic Zopiclone. Br J Clin Pharmacol. 1984;6:879-886. 
[13] Challenor VR, AG; Gruchy, BS; Waller, D; George, CF. The Effects of Food and Posture on the Pharmacokinetics of a Novel Formulation of Nifedipine British journal of clinical pharmacology. 1985:550P-551P

[14] Challenor V, Waller DG, Gruchy BS, et al. The Effects of Food and Posture on the Pharmacokinetics of a Biphasic Release Preparation of Nifedipine. Br J Clin Pharmacol. 1986;5:565-570.

[15] Chernish SM, Rubin A, Rodda BE, et al. The Physiological Disposition of Fenoprofen in Man. Iv. The Effects of Position of Subject, Food Ingestion and Antacid Ingestion on the Plasma Levels of Orally Administered Fenoprofen. J Med. 1972;4:249-257.

[16] De Buck E, Van de Velde S. Towards Evidence Based Emergency Medicine: Best Bets from the Manchester Royal Infirmary. Bet 1. Optimal Body Position in Oral Poisoning Cases. Emerg Med J. 2010;12:952-953.

[17] Fitzgerald JD, Ruffin R, Smedstad KG, et al. Studies on the Pharmacokinetics and Pharmacodynamics of Atenolol in Man. Eur J Clin Pharmacol. 1978;2:81-89.

[18] Gawronska-Szklarz B, Stankowska-Chomicz A, Wojcicki J, et al. [Paracetamol Pharmacokinetics in Persons in Recumbent Position]. Pol Tyg Lek. 1985;10:309-311.

[19] Gundert-Remy U, Grzegorzewski C, Baldauf G, et al. [Effect of Food Ingestion and Distribution on the Resorption of Tolbutamide]. Verh Dtsch Ges Inn Med. 1975:1680-1682.

[20] Gundert Remy UW, E. Influence of Body Position and Composition of Meals on the Absorption of Different Drugs. NAUNYN-SCHMIED.ARCH.PHARM. . 1976:Sup.(No.111)

[21] Gupta SK, Yih BM, Atkinson L, et al. The Effect of Food, Time of Dosing, and Body Position on the Pharmacokinetics and Pharmacodynamics of Verapamil and Norverapamil. J Clin Pharmacol. 1995;11:1083-1093.

[22] Idkaidek N, Arafat T. Effect of Microgravity on the Pharmacokinetics of Ibuprofen in Humans. J Clin Pharmacol. 2011;12:1685-1689.

[23] Kishida M, Hukushima K, likura Y. [Posture and Circadian Variations in Serum Theophylline Concentrations]. Arerugi. 1990;10:1422-1426.

[24] Miranda JPP, L.M.; Vakil, B.J. Pharmacokinetics of Ampicillin During Ambulation and Recumbency. Current Therapeutic Research - Clinical and Experimental 1982;6 II:936-940.

[25] Modi MW, Hassett JM, Lalka D. Influence of Posture on Hepatic Perfusion and the Presystemic Biotransformation of Propranolol: Simulation of the Food Effect. Clin Pharmacol Ther. 1988;3:268-274. 
[26] Rumble RH, Roberts MS. Effects of Posture and Sleep on the Pharmacokinetics of Gentamicins C1, C1a and C2. New Zealand Medical Journal. 1987;822:255-255.

[27] Takizawa D, Hiraoka H, Nakamura K, et al. Influence of the Prone Position on Propofol Pharmacokinetics. Anaesthesia. 2004;12:1250-1251.

[28] Warren J. Theophylline Concentrations and Posture. Lancet. 1983;8354:850.

[29] Warren J. Posture and Theophylline Pharmacokinetics Sustained Release Theophylline and Nocturnal Asthma. International Workshop, Burgenstock, Switzerland. CURR. CLIN. PRACT. SER. 1985:60-68.

[30] Worytkiewicz-Nowakowska B, Guzik E. [First Aid in Acute Poisoning with Particular Reference to Transportation]. Wiad Lek. 1971;18:1791-1792.

[31] Nimmo WS, Prescott LF. The Influence of Posture on Paracetamol Absorption. British Journal of Clinical Pharmacology. 1978;4:348-349.

[32] Rumble RH, Roberts MS, Denton MJ. Effects of Posture and Sleep on the Pharmacokinetics of Paracetamol (Acetaminophen) and Its Metabolites. Clin Pharmacokinet. 1991;2:167-173.

[33] Vance MV, Selden BS, Clark RF. Optimal Patient Position for Transport and Initial Management of Toxic Ingestions. Ann Emerg Med. 1992;3:243-246.

[34] Wallden J, Thorn SE, Wattwil M. The Delay of Gastric Emptying Induced by Remifentanil Is Not Influenced by Posture. Anesth Analg. 2004;2:429-434, table of contents.

[35] Gibaldi M, Kanig JL. The Effect of Body Position and Ph on the Gastrointestinal Absorption of Salicylate and Creatinine in Man. Arch Int Pharmacodyn Ther. 1966;2:343-358.

[36] Klotz U, Ziegler G. Physiologic and Temporal Variation in Hepatic Elimination of Midazolam. Clin Pharmacol Ther. 1982;1:107-112.

[37] Renwick AG, Ahsan CH, Challenor VF, et al. The Influence of Posture on the Pharmacokinetics of Orally Administered Nifedipine. Br J Clin Pharmacol. 1992;4:332-336.

[38] Roberts MS, Denton MJ. Effect of Posture and Sleep on Pharmacokinetics. I. Amoxycillin. Eur J Clin Pharmacol. 1980;2:175-183.

[39] Warren JBC, F.; Barnes, P.J. Posture and Theophylline Kinetics. British Journal of Clinical Pharmacology 1985;5:707-709.

[40] Ahsan CHC, C.F.; Daniels, R.; Renwick, A.G.; Waller, D.G. . The Influence of Posture on the Pharmacokinetics of Nifedipine. British journal of clinical pharmacology. 1991;5:564p. 
[41] European Public Assessment Report on Buccolam (Midazolam) [Internet]. London, United Kingdom: European Medicines Agency; 2011 [updated 2018 Aug 20; cited 2018 Sept 10]. Available from:

http://www.ema.europa.eu/ema/index.jsp?curl=pages/medicines/human/me dicines/002267/human_med_001479.jsp\&mid=WC0b01ac058001d124.

[42] Bradley WB, Schnedorf JG, Ivy AC. The Rate of Absorption of Salicylates and the Effect of Certain Compounds on the Rate of Absorption of Acetylsalicylic Acid from the Stomach and Intestine. American Journal of Digestive Diseases and Nutrition. 1936:415-419.

[43] Truitt EB, Morgan AM. Gastrointestinal Factors in Aspirin Absorption: A Quantitative Study. Journal of Pharmaceutical Sciences. 1964;2:129-134.

[44] Loots C, Smits M, Omari T, et al. Effect of Lateral Positioning on Gastroesophageal Reflux (Ger) and Underlying Mechanisms in Ger Disease (Gerd) Patients and Healthy Controls. Neurogastroenterol Motil. 2013;3:222229, e161-222.

[45] Valeur J, Berstad A, Hausken T. The Effect of Body Position on Postprandial Perceptions, Gastric Emptying, and Intragastric Meal Distribution: An Ultrasonographic Study in Reclining Healthy Subjects. Scand J Gastroenterol. 2015;2:170-173.

[46] van Wijk MP, Benninga MA, Dent J, et al. Effect of Body Position Changes on Postprandial Gastroesophageal Reflux and Gastric Emptying in the Healthy Premature Neonate. J Pediatr. 2007;6:585-590, 590 e581-582. 


\section{Figures:}

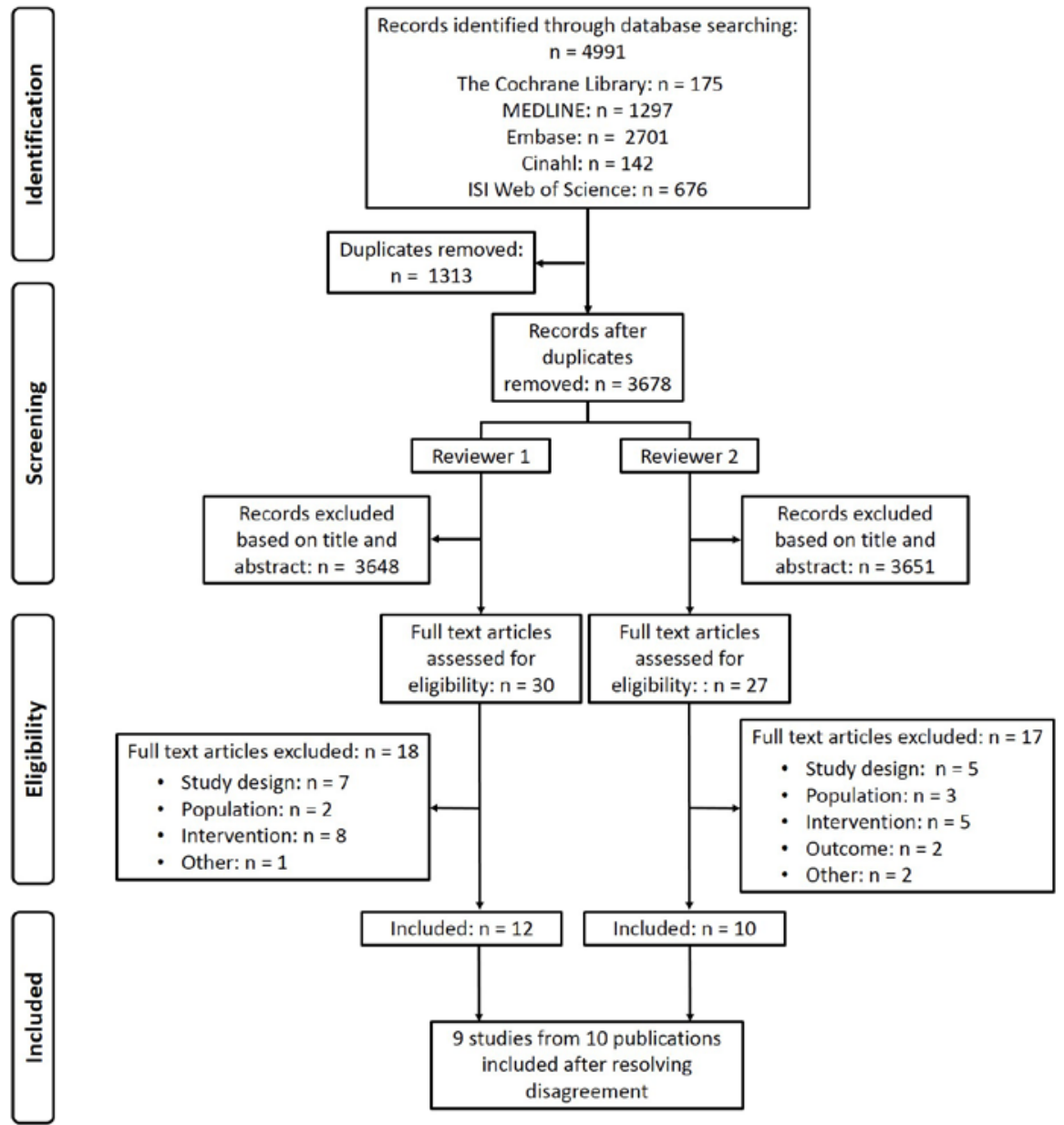

Figure 1: Flowchart of study selection.

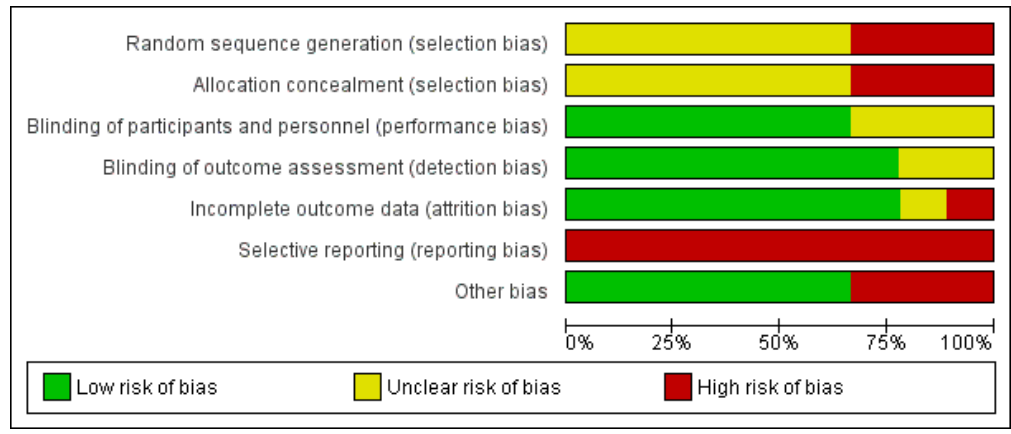

Figure 2: Risk of bias graph: review authors' judgements about each risk of bias item presented as percentages across all included studies. 


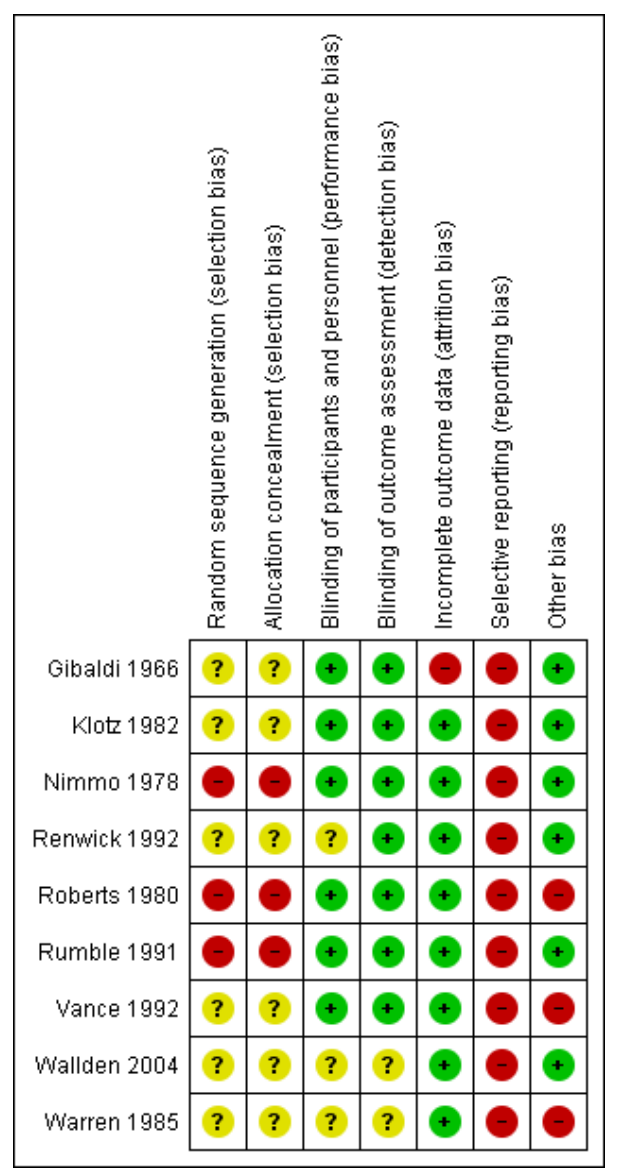

Figure 3: Risk of bias summary: review authors' judgments about each risk of bias item for each included study. 


\section{Table 1: Excluded studies}

\begin{tabular}{|c|c|c|c|}
\hline First author & Year & Title & Reason for exclusion \\
\hline $\begin{array}{l}\text { Appadu et al. } \\
\text { [7] }\end{array}$ & 1995 & $\begin{array}{l}\text { The effects of posture on gastric } \\
\text { emptying }\end{array}$ & $\begin{array}{l}\text { Ineligible outcome: no meas- } \\
\text { urement of drug } \\
\text { concentrations or drug effects }\end{array}$ \\
\hline Arena [8] & 1975 & $\begin{array}{l}\text { Poisoning - treatment and preven- } \\
\text { tion. Part I }\end{array}$ & $\begin{array}{l}\text { Ineligible study design: narra- } \\
\text { tive review }\end{array}$ \\
\hline Arena [9] & 1975 & $\begin{array}{l}\text { Poisoning - general treatment and } \\
\text { prevention. Part II }\end{array}$ & $\begin{array}{l}\text { Ineligible study design: narra- } \\
\text { tive review }\end{array}$ \\
\hline $\begin{array}{l}\text { Backon and } \\
\text { Hoffmann } \\
{[10]}\end{array}$ & 1991 & $\begin{array}{l}\text { The lateral decubitus position may } \\
\text { affect gastric emptying through an } \\
\text { autonomic mechanism: the skin } \\
\text { pressure-vegetative reflex }\end{array}$ & $\begin{array}{l}\text { Ineligible study design: letter to } \\
\text { the editor }\end{array}$ \\
\hline $\begin{array}{l}\text { Bani et al. } \\
{[11]}\end{array}$ & 2000 & $\begin{array}{l}\text { A double-blind, placebo-controlled } \\
\text { study to access tolerability, pharma- } \\
\text { cokinetics and preliminary } \\
\text { pharmacodynamics of single escalat- } \\
\text { ing doses of Z13752A, a novel dual } \\
\text { inhibitor of the metalloproteases ACE } \\
\text { and NEP, in healthy volunteers }\end{array}$ & $\begin{array}{l}\text { Ineligible intervention: not body } \\
\text { position }\end{array}$ \\
\hline $\begin{array}{l}\text { Channer et } \\
\text { al. [12] }\end{array}$ & 1984 & $\begin{array}{l}\text { The effect of posture at the time of } \\
\text { administration on the central depres- } \\
\text { sant effects of the new hypnotic } \\
\text { zopiclone }\end{array}$ & $\begin{array}{l}\text { Ineligible intervention: drug in- } \\
\text { take in upright or lying position, } \\
\text { but subjects remained supine } \\
\text { afterwards in both groups }\end{array}$ \\
\hline $\begin{array}{l}\text { Challenor et } \\
\text { al. [13] }\end{array}$ & 1986 & $\begin{array}{l}\text { The effects of food and posture on } \\
\text { the pharmacokinetics of a biphasic } \\
\text { release preparation of nifedipine }\end{array}$ & $\begin{array}{l}\text { Ineligible intervention: no com- } \\
\text { parison of different body } \\
\text { positions }\end{array}$ \\
\hline $\begin{array}{l}\text { Challenor et } \\
\text { al. [14] }\end{array}$ & 1985 & $\begin{array}{l}\text { The effects of food and posture on } \\
\text { the pharmacokinetics of a novel for- } \\
\text { mulation of nifedipine }\end{array}$ & Not available \\
\hline $\begin{array}{l}\text { Chernish et } \\
\text { al. [15] }\end{array}$ & 1972 & $\begin{array}{l}\text { The physiological disposition of } \\
\text { fenoprofen in man. IV. The effects of } \\
\text { position of subject, food ingestion } \\
\text { and antacid ingestion on the plasma } \\
\text { levels of orally administered } \\
\text { fenoprofen }\end{array}$ & $\begin{array}{l}\text { Ineligible intervention: combi- } \\
\text { nation of different body } \\
\text { positions, no control group }\end{array}$ \\
\hline $\begin{array}{l}\text { De Buck and } \\
\text { Van de Velde } \\
{[16]}\end{array}$ & 2010 & $\begin{array}{l}\text { Optimal body position in oral poison- } \\
\text { ing cases }\end{array}$ & $\begin{array}{l}\text { Relevant study in systematic } \\
\text { review already included from } \\
\text { the search }\end{array}$ \\
\hline $\begin{array}{l}\text { Fitzgerald et } \\
\text { al. [17] }\end{array}$ & 1978 & $\begin{array}{l}\text { Studies on the pharmacokinetics and } \\
\text { pharmacodynamics of atenolol in } \\
\text { man }\end{array}$ & $\begin{array}{l}\text { Ineligible intervention: no com- } \\
\text { parison of different body } \\
\text { positions }\end{array}$ \\
\hline $\begin{array}{l}\text { Gawronska- } \\
\text { Szklarz et al. } \\
{[18]}\end{array}$ & 1985 & $\begin{array}{l}\text { Paracetamol pharmacokinetics in } \\
\text { persons in recumbent position }\end{array}$ & $\begin{array}{l}\text { Ineligible population: drug up- } \\
\text { take in participants who have } \\
\text { been lying down or have been } \\
\text { active for a week. }\end{array}$ \\
\hline $\begin{array}{l}\text { Gundert } \\
\text { Remy et al. } \\
{[19]}\end{array}$ & 1975 & $\begin{array}{l}\text { Effect of food ingestion and distribu- } \\
\text { tion on the resorption of tolbutamide }\end{array}$ & $\begin{array}{l}\text { Ineligible intervention: food in- } \\
\text { gestion }\end{array}$ \\
\hline $\begin{array}{l}\text { Gundert } \\
\text { Remy and } \\
\text { Weber [20] }\end{array}$ & 1976 & $\begin{array}{l}\text { Influence of body position and com- } \\
\text { position of meals on the absorption } \\
\text { of different drugs }\end{array}$ & $\begin{array}{l}\text { Ineligible intervention: physical } \\
\text { activity }\end{array}$ \\
\hline $\begin{array}{l}\text { Gupta et al. } \\
\text { [21] }\end{array}$ & 1995 & $\begin{array}{l}\text { The effect of food, time of dosing, } \\
\text { and body position on the pharmaco- } \\
\text { kinetics and pharmacodynamics of } \\
\text { verapamil and norverapamil }\end{array}$ & $\begin{array}{l}\text { Ineligible population: no acute } \\
\text { oral ingestion, but chronic in- } \\
\text { gestion of drugs }\end{array}$ \\
\hline $\begin{array}{l}\text { Idkaidek and } \\
\text { Arafat [22] }\end{array}$ & 2011 & $\begin{array}{l}\text { Effect of microgravity on the pharma- } \\
\text { cokinetics of Ibuprofen in humans }\end{array}$ & $\begin{array}{l}\text { Ineligible intervention: micro- } \\
\text { gravity }\end{array}$ \\
\hline
\end{tabular}




\begin{tabular}{|l|l|l|l|}
\hline $\begin{array}{l}\text { Kishida et al. } \\
\text { [23] }\end{array}$ & 1990 & $\begin{array}{l}\text { Posture and circadian variations in } \\
\text { serum theophylline concentrations }\end{array}$ & $\begin{array}{l}\text { Ineligible population: asthmatic } \\
\text { children }\end{array}$ \\
\hline $\begin{array}{l}\text { Miranda et al. } \\
\text { [24] }\end{array}$ & 1982 & $\begin{array}{l}\text { Pharmacokinetics of ampicillin during } \\
\text { ambulation and recumbency }\end{array}$ & Ineligible intervention: sleeping \\
\hline $\begin{array}{l}\text { Modi et al. } \\
\text { [25] }\end{array}$ & 1988 & $\begin{array}{l}\text { Influence of posture on hepatic per- } \\
\text { fusion and the presystemic } \\
\text { biotransformation of propranolol: } \\
\text { simulation of the food effect. }\end{array}$ & $\begin{array}{l}\text { Ineligible intervention: compar- } \\
\text { ison of a combination of } \\
\text { positions in different orders }\end{array}$ \\
\hline $\begin{array}{l}\text { Rumble and } \\
\text { Roberts [26] }\end{array}$ & 1987 & $\begin{array}{l}\text { Effects of Posture and Sleep on the } \\
\text { Pharmacokinetics of Gentamicins } \\
\text { C1, C1a and C2 }\end{array}$ & $\begin{array}{l}\text { Ineligible study design: confer- } \\
\text { ence abstract without useable } \\
\text { data }\end{array}$ \\
\hline $\begin{array}{l}\text { Takizawa et } \\
\text { al. [27] }\end{array}$ & 2004 & $\begin{array}{l}\text { Influence of the prone position on } \\
\text { propofol pharmacokinetics }\end{array}$ & $\begin{array}{l}\text { Ineligible population: patients } \\
\text { undergoing spinal surgery }\end{array}$ \\
\hline Warren [28] & 1983 & $\begin{array}{l}\text { Theophylline concentrations and } \\
\text { posture }\end{array}$ & $\begin{array}{l}\text { Ineligible study design: letter to } \\
\text { the editor }\end{array}$ \\
\hline Warren [29] & 1985 & $\begin{array}{l}\text { Posture and theophylline pharmaco- } \\
\text { kinetics Sustained Release } \\
\text { Theophylline and Nocturnal Asthma. }\end{array}$ & $\begin{array}{l}\text { Ineligible study design: work- } \\
\text { shop }\end{array}$ \\
\hline $\begin{array}{l}\text { Worythiewicz- } \\
\text { Nowzkowska } \\
\text { and Guzik } \\
\text { [30] }\end{array}$ & 1971 & $\begin{array}{l}\text { First aid in acute poisoning with par- } \\
\text { ticular reference to transportation }\end{array}$ & $\begin{array}{l}\text { Ineligible study design: case } \\
\text { reports }\end{array}$ \\
\hline
\end{tabular}


Table 2: Characteristics of included studies

\begin{tabular}{|c|c|c|c|c|}
\hline $\begin{array}{l}\text { Author, } \\
\text { year, } \\
\text { Country }\end{array}$ & Study design & Population & Comparison & $\begin{array}{l}\text { Outcomes of } \\
\text { interest re- } \\
\text { ported }\end{array}$ \\
\hline $\begin{array}{l}\text { Gibaldi et } \\
\text { al., 1966, } \\
\text { USA [35] }\end{array}$ & $\begin{array}{l}\text { Experimental: } \\
\text { randomized } \\
\text { cross-over trial } \\
\text { (within sub- } \\
\text { jects) }\end{array}$ & $\begin{array}{l}6 \text { healthy male adults in- } \\
\text { gested } 0.3 \mathrm{~g} \text { crystalline } \\
\text { sodium salicylate or } 2.0 \\
\mathrm{~g} \text { creatinine dissolved in } \\
25 \mathrm{ml} \text { of distilled water } \\
\text { while in the test position. } \\
\text { Subjects fasted for at } \\
\text { least } 9 \mathrm{~h} \text { before and } 2 \mathrm{~h} \\
\text { after the start of each } \\
\text { experiment, after which } \\
\text { they were allowed to re- } \\
\text { turn to accustomed diet, } \\
\text { with the exclusion of di- } \\
\text { etary products. } \\
\text { [only data for sodium sa- } \\
\text { licylate was extracted] }\end{array}$ & $\begin{array}{l}\text { - Left lateral position: } \\
\text { during and } 1 \mathrm{~h} \text { after } \\
\text { drug intake, during } \\
\text { which the participant } \\
\text { was essentially immo- } \\
\text { bile with all body } \\
\text { movement kept to a } \\
\text { minimum. } \\
\text { - Ambulatory: during } \\
\text { and } 1 \mathrm{~h} \text { after drug in- } \\
\text { take. }\end{array}$ & $\begin{array}{l}\text { Salicyluric acid } \\
\text { (metabolite of } \\
\text { salicylic acid): } \\
\text { Cumulative uri- } \\
\text { nary excretion } \\
\text { (mg) }\end{array}$ \\
\hline $\begin{array}{l}\text { Klotz and } \\
\text { Ziegler, } \\
\text { 1982, Ger- } \\
\text { many [36] }\end{array}$ & $\begin{array}{l}\text { Experimental: } \\
\text { Randomized } \\
\text { controlled trial } \\
\text { (within sub- } \\
\text { jects) }\end{array}$ & $\begin{array}{l}6 \text { drug- and alcohol free } \\
\text { healthy male volunteers } \\
\text { with a normal sleep- } \\
\text { wake pattern (aged } 24- \\
38 \text { years) who ingested } \\
\text { a single oral dose of } 15 \\
\text { mg midazolam or } 0.075 \\
\mathrm{mg} / \mathrm{kg} \text { IV midazolam, } \\
\text { light meals were allowed } \\
2 \mathrm{~h} \text { after dosing. } \\
\text { [only data for oral mid- } \\
\text { azolam were extracted] }\end{array}$ & 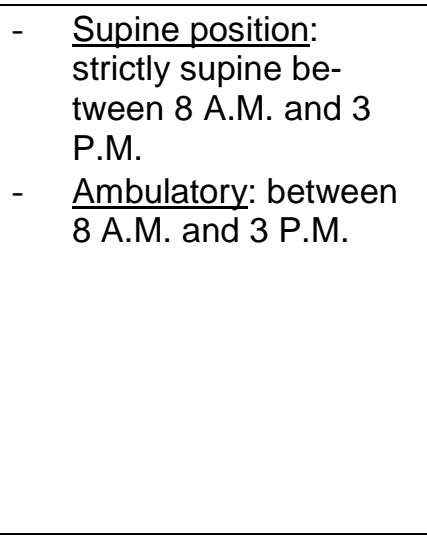 & $\begin{array}{l}\text { Midazolam: } \\
-\quad T_{\max }(\mathrm{h}) \\
-\quad C_{\max }(\mathrm{ng} / \mathrm{mL})\end{array}$ \\
\hline $\begin{array}{l}\text { Nimmo and } \\
\text { Prescott, } \\
\text { 1978, Scot- } \\
\text { land [31] }\end{array}$ & $\begin{array}{l}\text { Experimental: } \\
\text { Randomized } \\
\text { controlled trial } \\
\text { (within sub- } \\
\text { jects) }\end{array}$ & $\begin{array}{l}8 \text { healthy volunteers } \\
\text { (aged } 29 \pm 1.8 \text { years) } \\
\text { who ingested } 1.5 \mathrm{~g} \text { pa- } \\
\text { racetamol ( } 3 \text { Panadol } \\
\text { tablets) ingested with } \\
200 \text { ml of water, after an } \\
\text { overnight fast. No food, } \\
\text { fluid or tobacco were al- } \\
\text { lowed during the study } \\
\text { period. }\end{array}$ & 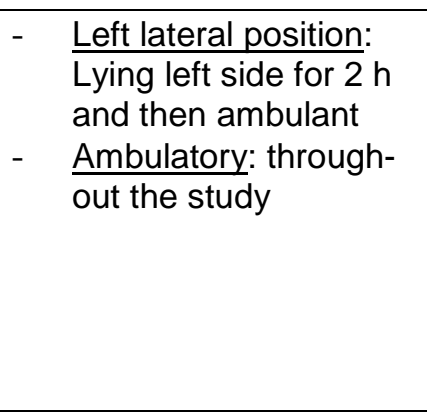 & $\begin{array}{l}\text { Paracetamol: } \\
\text { AUC } 0-4 h \\
((\mu \mathrm{g} / \mathrm{ml}) \times \mathrm{xh})\end{array}$ \\
\hline $\begin{array}{l}\text { Renwick et } \\
\text { al., 1992, } \\
\text { UK [37] }\end{array}$ & $\begin{array}{l}\text { Experimental: } \\
\text { Randomized } \\
\text { controlled trial } \\
\text { (within sub- } \\
\text { jects) }\end{array}$ & $\begin{array}{l}8 \text { healthy non-smoking } \\
\text { volunteers, not taking } \\
\text { any concomitant medi- } \\
\text { cation (aged } 21-23 \\
\text { years; } 6 \text { males, } 2 \text { fe- } \\
\text { males), who ingested } \\
2 \times 10 \text { mg capsules of ni- } \\
\text { fedipine }+1 \text { g soluble } \\
\text { paracetamol following } \\
\text { an overnight fast. After } 4 \\
\text { h subjects were allowed } \\
\text { to drink and eat and to } \\
\text { resume normal activi- } \\
\text { ties. }\end{array}$ & $\begin{array}{ll}\text { - } & \text { Left lateral position: } \\
\text { Lying on the left side } \\
\text { for } 4 \mathrm{~h} \\
\text { - } \\
\text { Right lateral position: } \\
\text { Lying on the right side } \\
\text { for } 4 \mathrm{~h} \\
\text { - } \\
\text { Upright position: } \\
\text { Standing for } 4 \mathrm{~h}\end{array}$ & $\begin{array}{l}\text { Nifedipine and } \\
\text { paracetamol: } \\
\text { - } C_{\max }(\mu \mathrm{g} / \mathrm{ml} \text { or } \\
\mathrm{ng} / \mathrm{ml}) \\
-T_{\max }(\mathrm{h}) \\
- \text { AUC } \\
((\mu \mathrm{g} / \mathrm{ml}) \mathrm{xh} \text { or } \\
(\mathrm{ng} / \mathrm{ml}) \mathrm{xh})\end{array}$ \\
\hline
\end{tabular}




\begin{tabular}{|c|c|c|c|c|}
\hline $\begin{array}{l}\text { Roberts } \\
\text { and Den- } \\
\text { ton, 1980, } \\
\text { Australia } \\
\text { [38] }\end{array}$ & $\begin{array}{l}\text { Experimental: } \\
\text { Randomized } \\
\text { controlled trial } \\
\text { (within sub- } \\
\text { jects) }\end{array}$ & $\begin{array}{l}8 \text { healthy male volun- } \\
\text { teers (aged } 22.75 \pm 1.58 \\
\text { years) who ingested } 250 \\
\text { mg amoxicillin capsules } \\
\text { with } 250 \text { ml water, after } \\
\text { fasting } 2 \text { hours. No food } \\
\text { was allowed up to } 2 \mathrm{~h} \\
\text { after dosing. }\end{array}$ & $\begin{array}{ll}- & \text { Bed rest during day- } \\
\text { time: position not } \\
\text { specified } \\
- & \text { Bed rest at night: } \\
\text { position not specified } \\
- & \frac{\text { Ambulatory: during }}{\text { the day }} \\
& \\
\text { [data from bed rest at } \\
\text { night was not extracted] }\end{array}$ & $\begin{array}{l}\text { Amoxicillin: } \\
- \text { AUC }_{0-\infty} \\
\quad((\mathrm{mg} / \mathrm{L}) \mathrm{xh}) \\
-\mathrm{C}_{\max }(\mathrm{mg} / \mathrm{L}) \\
-\mathrm{T}_{\max }(\mathrm{min})\end{array}$ \\
\hline $\begin{array}{l}\text { Rumble et } \\
\text { al., 1991, } \\
\text { Australia } \\
{[32]}\end{array}$ & $\begin{array}{l}\text { Experimental: } \\
\text { Randomized } \\
\text { controlled trial } \\
\text { (within sub- } \\
\text { jects) }\end{array}$ & $\begin{array}{l}8 \text { healthy male volun- } \\
\text { teers (aged } 21-26 \\
\text { years) who ingested } 500 \\
\text { mg paracetamol with } \\
200 \text { ml water, after a } 2 \mathrm{~h} \\
\text { fast. No food was al- } \\
\text { lowed for } 2 \mathrm{~h} \text { after } \\
\text { dosing. }\end{array}$ & $\begin{array}{ll}\text { - } & \text { Bed rest during day- } \\
\text { time: } \\
\text { position not specified } \\
-\quad \text { Ambulatory: } \\
\text { during daytime. }\end{array}$ & 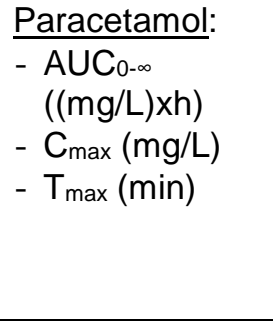 \\
\hline $\begin{array}{l}\text { Vance et } \\
\text { al., 1992, } \\
\text { USA [33] }\end{array}$ & $\begin{array}{l}\text { Experimental: } \\
\text { Randomized } \\
\text { controlled trial } \\
\text { (within sub- } \\
\text { jects) }\end{array}$ & $\begin{array}{l}12 \text { healthy young volun- } \\
\text { teers ( } 6 \text { males and } 6 \\
\text { females), not concur- } \\
\text { rently taking } \\
\text { medications altering } \\
\text { gastrointestinal function, } \\
\text { who ingested } 80 \mathrm{mg} / \mathrm{kg} \\
\text { paracetamol as } 160 \mathrm{mg} \\
\text { children's tablets, within } \\
60 \text { seconds, after an } 8 \mathrm{~h} \\
\text { fast and refraining from } \\
\text { paracetamol use for } 3 \\
\text { days before study and } \\
\text { during wash-out peri- } \\
\text { ods. }\end{array}$ & $\begin{array}{ll}- & \text { Left lateral position } \\
- & \text { Right lateral position } \\
- & \text { Prone position } \\
- & \text { Upright position } \\
- & \text { Supine position } \\
\text { All positions were re- } \\
\text { mained for } 2 \mathrm{~h} \text { after drug } \\
\text { intake. }\end{array}$ & $\begin{array}{l}\text { Paracetamol: } \\
\text { AUC } 0-2 \\
((\mathrm{mg} / \mathrm{L}) \mathrm{xh})\end{array}$ \\
\hline $\begin{array}{l}\text { Wallden et } \\
\text { al., 2004, } \\
\text { Sweden } \\
{[34]}\end{array}$ & $\begin{array}{l}\text { Experimental: } \\
\text { Randomized } \\
\text { controlled trial } \\
\text { (within sub- } \\
\text { jects) }\end{array}$ & $\begin{array}{l}10 \text { healthy male volun- } \\
\text { teers (aged } 23.9 \text { (range } \\
21-31 \text { ) years) who in- } \\
\text { gested } 1.5 \mathrm{~g} \\
\text { paracetamol dissolved } \\
\text { in } 200 \mathrm{ml} \text { water with or } \\
\text { without a continuous in- } \\
\text { fusion of remifentanil. } \\
\text { Subjects fasted for at } \\
\text { least } 6 \text { h before each } \\
\text { study. } \\
\text { [data of phases with IV } \\
\text { remifentanil were not ex- } \\
\text { tracted] }\end{array}$ & $\begin{array}{l}- \\
\text { Left lateral position: } \\
\text { lying left with } 20^{\circ} \\
\text { head down tilt, un- } \\
\text { clear for how long } \\
-\quad \text { Right lateral position: } \\
\text { lying right with } 20^{\circ} \\
\text { head up tilt, unclear } \\
\text { for how long }\end{array}$ & $\begin{array}{l}\text { Paracetamol: } \\
\text { - AUC } \mathrm{C}_{0-60} \\
((\mu \mathrm{mol} / \mathrm{L}) \times \mathrm{min}) \\
-\mathrm{C}_{\max }(\mu \mathrm{mol} / \mathrm{L}) \\
-\mathrm{T}_{\max }(\mathrm{min}) \\
\text { - Incidence of } \\
\text { adverse } \\
\text { events (nau- } \\
\text { sea, vomiting, } \\
\text { pruritus) }\end{array}$ \\
\hline $\begin{array}{l}\text { Warren and } \\
\text { Barnes, } \\
\text { 1985, UK } \\
\text { [39] }\end{array}$ & $\begin{array}{l}\text { Experimental: } \\
\text { Randomized } \\
\text { controlled trial } \\
\text { (within sub- } \\
\text { jects) }\end{array}$ & $\begin{array}{l}6 \text { healthy, non-smoking } \\
\text { male volunteers among } \\
\text { hospital personnel } \\
\text { (aged } 25-33 \text { years) who } \\
\text { ingested } 450 \text { mg of slow } \\
\text { release theophylline ( } 2 \\
\text { tablets of Phyllocontin), } \\
\text { taken between } 7 \text { h00 } \\
\text { and } 9 \text { h30 after an over- } \\
\text { night fast. Breakfast and } \\
\text { lunch were allowed at } 1\end{array}$ & $\begin{array}{ll} & \text { Supine position: } \\
\text { for } 6 \mathrm{~h} \text { after drug in- } \\
\text { gestion } \\
\text { - } \\
\text { Ambulatory: } \\
\text { Standing/walking for } 6 \\
\text { h after drug ingestion }\end{array}$ & Adverse events \\
\hline
\end{tabular}




\begin{tabular}{|l|l|l|l|}
\hline & \multicolumn{1}{|c|}{$\begin{array}{l}\mathrm{h} \text { and } 4 \mathrm{~h} \text { after drug ad- } \\
\text { ministration. }\end{array}$} & & \\
\hline
\end{tabular}


Table 3: Synthesis of findings

\begin{tabular}{|c|c|c|c|c|c|}
\hline Drug & Outcome & Comparison & Effect size & \# participants & Reference \\
\hline \multirow[t]{14}{*}{ Paracetamol } & $\begin{array}{l}\operatorname{AUC}_{(0-60} \\
\min ) \\
((\mu \mathrm{mol} / L) x \\
\min )\end{array}$ & $\begin{array}{l}\text { Left lateral po- } \\
\text { sition with } 20^{\circ} \\
\text { head down tilt } \\
\text { vs right lateral } \\
\text { position with } \\
20^{\circ} \text { head up } \\
\text { tilt }\end{array}$ & $\begin{array}{l}\text { Statistically significant: } \\
3793 \pm 1307 \text { vs } 5092 \pm 1125 \\
\text { MD: }-1299 \mathrm{E} \dagger \\
(p<0.0083) \\
\text { In favour of left lateral position } \\
\text { with } 20^{\circ} \text { head down tilt }\end{array}$ & $\begin{array}{l}10 \text { vs } 10 \\
\text { (within sub- } \\
\text { jects) }\end{array}$ & $\begin{array}{l}\text { Wallden et } \\
\text { al., } 2004 \\
\text { [34] }\end{array}$ \\
\hline & \multirow[t]{10}{*}{$\begin{array}{l}\operatorname{AUC}_{(0-2 h)} \\
((\mathrm{mg} / \mathrm{l}) \mathrm{X} \\
\min )\end{array}$} & $\begin{array}{l}\text { Left lateral vs } \\
\text { supine position }\end{array}$ & $\begin{array}{l}\text { Not statistically significant: } \\
6006 \pm 2614 \text { vs } 6649 \pm 2716 \\
\text { MD: }-643 £ \dagger \\
(p>0.05)\end{array}$ & \multirow[t]{10}{*}{$\begin{array}{l}12 \text { vs } 12 \S \\
\text { (within sub- } \\
\text { jects) }\end{array}$} & \multirow[t]{10}{*}{$\begin{array}{l}\text { Vance et } \\
\text { al., } 1992 \\
{[33]}\end{array}$} \\
\hline & & $\begin{array}{l}\text { Right lateral vs } \\
\text { supine position }\end{array}$ & $\begin{array}{l}\text { Statistically significant: } \\
8950 \pm 1405 \text { vs } 6649 \pm 2716 \\
\text { MD: } 2301 £ \dagger \\
(p<0.05) \\
\text { In favour of supine position }\end{array}$ & & \\
\hline & & $\begin{array}{l}\text { Sitting vs su- } \\
\text { pine position }\end{array}$ & $\begin{array}{l}\text { Statistically significant: } \\
8608 \pm 1725 \text { vs } 6649 \pm 2716 \\
\text { MD: } 1959 £ \dagger \\
(p<0.05) \\
\text { In favour of supine position }\end{array}$ & & \\
\hline & & $\begin{array}{l}\text { Prone vs su- } \\
\text { pine position }\end{array}$ & $\begin{array}{l}\text { Statistically significant: } \\
7432 \pm 1809 \text { vs } 6649 \pm 2716 \\
\text { MD: } 783 £ \dagger \\
(p<0.05) \\
\text { In favour of supine position }\end{array}$ & & \\
\hline & & $\begin{array}{l}\text { Right lateral vs } \\
\text { left lateral po- } \\
\text { sition }\end{array}$ & $\begin{array}{l}\text { Statistically significant: } \\
8950 \pm 1405 \text { vs } 6006 \pm 2614 \\
\text { MD: } 2944 £ \dagger \\
(p<0.05) \\
\text { In favour of left lateral position }\end{array}$ & & \\
\hline & & $\begin{array}{l}\text { Sitting vs left } \\
\text { lateral position }\end{array}$ & $\begin{array}{l}\text { Statistically significant: } \\
8608 \pm 1725 \text { vs } 6006 \pm 2614 \\
\text { MD: } 2602 £ \dagger \\
(p<0.05) \\
\text { In favour of left lateral position }\end{array}$ & & \\
\hline & & $\begin{array}{l}\text { Prone vs left } \\
\text { lateral position }\end{array}$ & $\begin{array}{l}\text { Statistically significant: } \\
7432 \pm 1809 \text { vs } 6006 \pm 2614 \\
\text { MD: } 1426 £ \dagger \\
(p<0.05) \\
\text { In favour of left lateral decubitus }\end{array}$ & & \\
\hline & & $\begin{array}{l}\text { Sitting vs right } \\
\text { lateral position }\end{array}$ & $\begin{array}{l}\text { No statement of significance } \\
\text { made }\end{array}$ & & \\
\hline & & $\begin{array}{l}\text { Prone vs right } \\
\text { lateral position }\end{array}$ & $\begin{array}{l}\text { No statement of significance } \\
\text { made }\end{array}$ & & \\
\hline & & $\begin{array}{l}\text { Prone vs sit- } \\
\text { ting position }\end{array}$ & $\begin{array}{l}\text { No statement of significance } \\
\text { made }\end{array}$ & & \\
\hline & $\begin{array}{l}\mathrm{AUC}_{(0-4 h)} \\
((\mu \mathrm{g} / \mathrm{ml}) \mathrm{x} \\
\mathrm{h})\end{array}$ & $\begin{array}{l}\text { Left lateral po- } \\
\text { sition vs } \\
\text { ambulatory }\end{array}$ & $\begin{array}{l}\text { Not statistically significant: } \\
45.5 \pm 7.9 \text { vs } 49.5 \pm 12.2 \\
\text { MD: }-4.0 £ \dagger \\
(p>0.05)\end{array}$ & \multirow[t]{3}{*}{$\begin{array}{l}8 \text { vs } 8 \S \\
\text { (within sub- } \\
\text { jects) }\end{array}$} & $\begin{array}{l}\text { Nimmo and } \\
\text { Prescott, } \\
1978 \text { [31] }\end{array}$ \\
\hline & \multirow[t]{2}{*}{$\begin{array}{l}\mathrm{AUC}_{(0-24 h)} \\
((\mu \mathrm{g} / \mathrm{ml}) \mathrm{x} \\
\mathrm{h})\end{array}$} & $\begin{array}{l}\text { Left lateral po- } \\
\text { sition vs right } \\
\text { lateral position }\end{array}$ & $\begin{array}{l}\text { Not statistically significant: } \\
44.5 \pm 14.1 \text { vs } 47.6 \pm 15.1 \\
\text { MD: }-3.1 £ \dagger \\
(p>0.05)\end{array}$ & & \multirow[t]{2}{*}{$\begin{array}{l}\text { Renwick et } \\
\text { al., } 1992 \\
\text { [37] }\end{array}$} \\
\hline & & $\begin{array}{l}\text { Left lateral po- } \\
\text { sition vs } \\
\text { standing }\end{array}$ & $\begin{array}{l}\text { Not statistically significant: } \\
44.5 \pm 14.1 \text { vs } 44.1 \pm 7.1 \\
\text { MD: } 0.4 £ \dagger \\
(p>0.05)\end{array}$ & & \\
\hline
\end{tabular}




\begin{tabular}{|c|c|c|c|c|c|}
\hline & & $\begin{array}{l}\text { Right lateral } \\
\text { position vs } \\
\text { standing }\end{array}$ & $\begin{array}{l}\text { Not statistically significant: } \\
47.6 \pm 15.1 \text { vs } 44.1 \pm 7.1 \\
\text { MD: } 3.5 £ \dagger \\
(p>0.05)\end{array}$ & & \\
\hline & $\begin{array}{l}\mathrm{AUC}_{0-\infty} \\
((\mathrm{mg} / \mathrm{L}) \times \mathrm{h})\end{array}$ & $\begin{array}{l}\text { Bed rest vs } \\
\text { ambulatory }\end{array}$ & $\begin{array}{l}\text { Not statistically significant: } \\
24.4 \pm 8.9 \text { vs } 25.4 \pm 7.1 \\
\text { MD: }-1.0 £ \dagger \\
(p>0.05)\end{array}$ & & $\begin{array}{l}\text { Rumble et } \\
\text { al., } 1991 \\
{[32]}\end{array}$ \\
\hline & $\begin{array}{l}C_{\max } \\
(\mu \mathrm{g} / \mathrm{ml})\end{array}$ & $\begin{array}{l}\text { Left lateral po- } \\
\text { sition vs right } \\
\text { lateral position }\end{array}$ & $\begin{array}{l}\text { Not statistically significant: } \\
18.3 \pm 7.2 \text { vs } 23.1 \pm 5.5 \\
\text { MD: }-4.8 £ \dagger \\
(p>0.05)\end{array}$ & & $\begin{array}{l}\text { Renwick et } \\
\text { al., } 1992 \\
{[37]}\end{array}$ \\
\hline & & $\begin{array}{l}\text { Left lateral po- } \\
\text { sition vs } \\
\text { standing }\end{array}$ & $\begin{array}{l}\text { Not statistically significant: } \\
18.3 \pm 7.2 \text { vs } 20.6 \pm 6.2 \\
\text { MD: }-2.3 £ \dagger \\
(p>0.05)\end{array}$ & & \\
\hline & & $\begin{array}{l}\text { Right lateral } \\
\text { position vs } \\
\text { standing }\end{array}$ & $\begin{array}{l}\text { Not statistically significant: } \\
23.1 \pm 5.5 \text { vs } 20.6 \pm 6.2 \\
\text { MD: } 2.5 £ \dagger \\
(p>0.05)\end{array}$ & & \\
\hline & $\begin{array}{l}\mathrm{C}_{\max } \\
(\mathrm{mg} / \mathrm{ml})\end{array}$ & $\begin{array}{l}\text { Bed rest vs } \\
\text { ambulatory }\end{array}$ & $\begin{array}{l}\text { Not statistically significant: } \\
8.65 \pm 2.65 \text { vs } 9.47 \pm 4.18 \\
\text { MD: }-0.82 £ \dagger \\
(p>0.05)\end{array}$ & & $\begin{array}{l}\text { Rumble et } \\
\text { al., } 1991 \\
\text { [32] }\end{array}$ \\
\hline & $\begin{array}{l}\mathrm{C}_{\max } \\
(\mu \mathrm{mol} / \mathrm{l})\end{array}$ & $\begin{array}{l}\text { Left lateral po- } \\
\text { sition with } 20^{\circ} \\
\text { head down tilt } \\
\text { vs right lateral } \\
\text { position with } \\
20^{\circ} \text { head up } \\
\text { tilt }\end{array}$ & $\begin{array}{l}\text { Statistically significant: } \\
94 \pm 30 \text { vs } 138 \pm 45 \\
M D:-44 £ \dagger \\
(p<0.0083) \\
\text { In favour of left lateral position } \\
\text { with } 20^{\circ} \text { head down tilt }\end{array}$ & $\begin{array}{l}10 \text { vs } 10 \\
\text { (within sub- } \\
\text { jects) }\end{array}$ & $\begin{array}{l}\text { Wallden et } \\
\text { al., } 2004 \\
\text { [34] }\end{array}$ \\
\hline & $\mathrm{T}_{\max }(\mathrm{h})$ & $\begin{array}{l}\text { Left lateral po- } \\
\text { sition vs right } \\
\text { lateral position }\end{array}$ & $\begin{array}{l}\text { Statistically significant: } \\
0.52 \pm 0.27 \text { vs } 0.34 \pm 0.19 \\
\text { MD: } 0.18 £ \dagger \\
(p<0.05) \\
\text { In favour of left lateral position }\end{array}$ & $\begin{array}{l}8 \text { vs } 8 \S \\
\text { (within sub- } \\
\text { jects) }\end{array}$ & $\begin{array}{l}\text { Renwick et } \\
\text { al., } 1992 \\
{[37]}\end{array}$ \\
\hline & & $\begin{array}{l}\text { Left lateral po- } \\
\text { sition vs } \\
\text { standing }\end{array}$ & $\begin{array}{l}\text { Statistically significant: } \\
0.52 \pm 0.27 \text { vs } 0.34 \pm 0.13 \\
\text { MD: } 0.18 £ \dagger \\
(p<0.05) \\
\text { In favour of left lateral position }\end{array}$ & & \\
\hline & & $\begin{array}{l}\text { Right lateral } \\
\text { position vs } \\
\text { standing }\end{array}$ & $\begin{array}{l}\text { Not statistically significant: } \\
0.34 \pm 0.19 \text { vs } 0.34 \pm 0.19 \\
\text { MD: } 0.00 £ \dagger \\
(p>0.05)\end{array}$ & & \\
\hline & $\mathrm{T}_{\max }(\min )$ & $\begin{array}{l}\text { Left lateral po- } \\
\text { sition with } 20^{\circ} \\
\text { head down tilt } \\
\text { vs right lateral } \\
\text { position with } \\
20^{\circ} \text { head up } \\
\text { tilt }\end{array}$ & $\begin{array}{l}\text { Not statistically significant: } \\
47 \pm 22 \text { vs } 25 \pm 14 \\
\text { MD: } 22 £ \dagger \\
(p>0.0083)\end{array}$ & $\begin{array}{l}10 \text { vs } 10 \\
\text { (within sub- } \\
\text { jects) }\end{array}$ & $\begin{array}{l}\text { Wallden et } \\
\text { al., } 2004 \\
{[34]}\end{array}$ \\
\hline & & $\begin{array}{l}\text { Bed rest vs } \\
\text { ambulatory }\end{array}$ & $\begin{array}{l}\text { Not statistically significant: } \\
54.5 \pm 29.7 \text { vs } 35.6 \pm 27.7 \\
\text { MD: } 18.9 £ \dagger \\
(p>0.05)\end{array}$ & $\begin{array}{l}8 \text { vs } 8 \S \\
\text { (within sub- } \\
\text { jects) }\end{array}$ & $\begin{array}{l}\text { Rumble et } \\
\text { al., } 1991 \\
\text { [32] }\end{array}$ \\
\hline $\begin{array}{l}\text { Paracetamol } \\
\text { glucuronide }\end{array}$ & & & $\begin{array}{l}\text { Not statistically significant : } \\
128.6 \pm 48.0 \text { vs } 105.0 \pm 22.6 \\
\text { MD: } 23.6 £ \dagger \\
(p>0.05)\end{array}$ & & \\
\hline $\begin{array}{l}\text { Paracetamol } \\
\text { sulphate }\end{array}$ & & & $\begin{array}{l}\text { Not statistically significant: } \\
84.4 \pm 42.4 \text { vs } 96.9 \pm 33.5 \\
\text { MD: }-12.5 £ \dagger \\
(p>0.05)\end{array}$ & & \\
\hline Paracetamol & Nausea & $\begin{array}{l}\text { Left lateral po- } \\
\text { sition with } 20^{\circ} \\
\text { head down tilt }\end{array}$ & $\begin{array}{l}\text { Not statistically significant: } \\
0 / 10 \text { vs } 0 / 10 \S \\
\text { RR not estimable }\end{array}$ & $\begin{array}{l}10 \text { vs } 10 \\
\text { (within sub- } \\
\text { jects) }\end{array}$ & $\begin{array}{l}\text { Wallden et } \\
\text { al., } 2004 \\
{[34]}\end{array}$ \\
\hline
\end{tabular}




\begin{tabular}{|c|c|c|c|c|c|}
\hline & Vomiting & \multirow{2}{*}{$\begin{array}{l}\text { vs right lateral } \\
\text { position with } \\
20^{\circ} \text { head up } \\
\text { tilt }\end{array}$} & $\begin{array}{l}\text { Not statistically significant: } \\
0 / 10 \text { vs } 0 / 10 \S \\
\text { RR not estimable }\end{array}$ & & \\
\hline & Pruritus & & $\begin{array}{l}\text { Not statistically significant: } \\
0 / 10 \text { vs } 0 / 10 \S \\
\text { RR not estimable }\end{array}$ & & \\
\hline \multirow[t]{11}{*}{ Nifedipine } & \multirow[t]{3}{*}{$\begin{array}{l}\mathrm{AUC}_{(0-24 h)} \\
((\mathrm{ng} / \mathrm{ml}) \mathrm{x} \\
\mathrm{h})\end{array}$} & $\begin{array}{l}\text { Left lateral po- } \\
\text { sition vs right } \\
\text { lateral position }\end{array}$ & $\begin{array}{l}\text { Statistically significant: } \\
354.1 \pm 109.6 \text { vs } 490.3 \pm 116.2 \\
\text { MD: }-136.2 £ \dagger \\
(p<0.01) \\
\text { In favour of left lateral position }\end{array}$ & \multirow[t]{13}{*}{$\begin{array}{l}8 \text { vs } 8 \S \\
\text { (within sub- } \\
\text { jects) }\end{array}$} & \multirow[t]{13}{*}{$\begin{array}{l}\text { Renwick e } \\
\text { al., } 1992 \\
\text { [37] }\end{array}$} \\
\hline & & $\begin{array}{l}\text { Left lateral po- } \\
\text { sition vs } \\
\text { standing }\end{array}$ & $\begin{array}{l}\text { Statistically significant: } \\
354.1 \pm 109.6 \text { vs } 460.3 \pm 143.1 \\
\text { MD: }-106.2 £ \dagger \\
(p<0.05) \\
\text { In favour of left lateral position }\end{array}$ & & \\
\hline & & $\begin{array}{l}\text { Right lateral } \\
\text { position vs } \\
\text { standing }\end{array}$ & $\begin{array}{l}\text { Not statistically significant: } \\
490.3 \pm 116.2 \text { vs } 460.3 \pm 143.1 \\
\text { MD: } 30 £ \dagger \\
(p>0.05)\end{array}$ & & \\
\hline & \multirow[t]{3}{*}{$\begin{array}{l}\mathrm{C}_{\max } \\
(\mathrm{ng} / \mathrm{ml})\end{array}$} & $\begin{array}{l}\text { Left lateral po- } \\
\text { sition vs right } \\
\text { lateral position }\end{array}$ & $\begin{array}{l}\text { Statistically significant: } \\
148.7 \pm 107.7 \text { vs } 267.9 \pm 78.4 \\
\text { MD: }-119.2 £ \dagger \\
(p<0.01) \\
\text { In favour of left lateral position }\end{array}$ & & \\
\hline & & $\begin{array}{l}\text { Left lateral po- } \\
\text { sition vs } \\
\text { standing }\end{array}$ & $\begin{array}{l}\text { Statistically significant: } \\
148.7 \pm 107.7 \text { vs } 369.6 \pm 100.8 \\
\text { MD: }-220.9 \pm \dagger \\
(p<0.01) \\
\text { In favour of left lateral position }\end{array}$ & & \\
\hline & & $\begin{array}{l}\text { Right lateral } \\
\text { position vs } \\
\text { standing }\end{array}$ & $\begin{array}{l}\text { Statistically significant: } \\
267.9 \pm 78.4 \text { vs } 369.6 \pm 100.8 \\
\text { MD: }-101.7 £ \dagger \\
(p<0.01) \\
\text { In favour of right lateral position }\end{array}$ & & \\
\hline & \multirow[t]{3}{*}{$\mathrm{T}_{\max }(\mathrm{h})$} & $\begin{array}{l}\text { Left lateral po- } \\
\text { sition vs right } \\
\text { lateral position }\end{array}$ & $\begin{array}{l}\text { Statistically significant: } \\
0.95 \pm 0.77 \text { vs } 0.45 \pm 0.10 \\
\text { MD: } 0.50 £ \dagger \\
(p<0.05) \\
\text { In favour of left lateral position }\end{array}$ & & \\
\hline & & $\begin{array}{l}\text { Left lateral po- } \\
\text { sition vs } \\
\text { standing }\end{array}$ & $\begin{array}{l}\text { Statistically significant: } \\
0.95 \pm 0.77 \text { vs } 0.32 \pm 0.09 \\
\text { MD: } 0.63 £ \dagger \\
(p<0.05) \\
\text { In favour of left lateral position }\end{array}$ & & \\
\hline & & $\begin{array}{l}\text { Right lateral } \\
\text { position vs } \\
\text { standing }\end{array}$ & $\begin{array}{l}\text { Statistically significant: } \\
0.45 \pm 0.10 \text { vs } 0.32 \pm 0.09 \\
\text { MD: } 0.13 £ \dagger \\
(p<0.05) \\
\text { In favour of right lateral position }\end{array}$ & & \\
\hline & $\begin{array}{l}\text { Pulse } \\
\text { rate } 0.5-4 \mathrm{~h} \\
\text { (bpm) }\end{array}$ & \multirow[t]{2}{*}{$\begin{array}{l}\text { Left lateral po- } \\
\text { sition vs right } \\
\text { lateral position }\end{array}$} & $\begin{array}{l}\text { Statistically significant: } \\
(p<0.05) £ £ \dagger \\
\text { In favour of left lateral position }\end{array}$ & & \\
\hline & $\begin{array}{l}\text { Diastolic } \\
\text { blood pres- } \\
\text { sure } 0.5-4 \mathrm{~h} \\
(\mathrm{mmHg})\end{array}$ & & $\begin{array}{l}\text { Not statistically significant: } \\
(p>0.05) £ £ \dagger\end{array}$ & & \\
\hline \multirow[t]{2}{*}{ Nitropyridine } & \multirow[t]{2}{*}{$\begin{array}{l}\mathrm{AUC}_{(0-24 \mathrm{~h})} \\
((\mathrm{ng} / \mathrm{ml}) \mathrm{x} \\
\mathrm{h})\end{array}$} & $\begin{array}{l}\text { Left lateral po- } \\
\text { sition vs right } \\
\text { lateral position }\end{array}$ & $\begin{array}{l}\text { Not statistically significant: } \\
185.6 \pm 45.8 \text { vs } 193.6 \pm 42.9 \\
\text { MD: }-8.0 £ \dagger \\
(p>0.05)\end{array}$ & & \\
\hline & & $\begin{array}{l}\text { Left lateral po- } \\
\text { sition vs } \\
\text { standing }\end{array}$ & $\begin{array}{l}\text { Not statistically significant: } \\
185.6 \pm 45.8 \text { vs } 179.7 \pm 42.1 \\
\text { MD: } 5.9 £ \dagger \\
(p>0.05)\end{array}$ & & \\
\hline
\end{tabular}




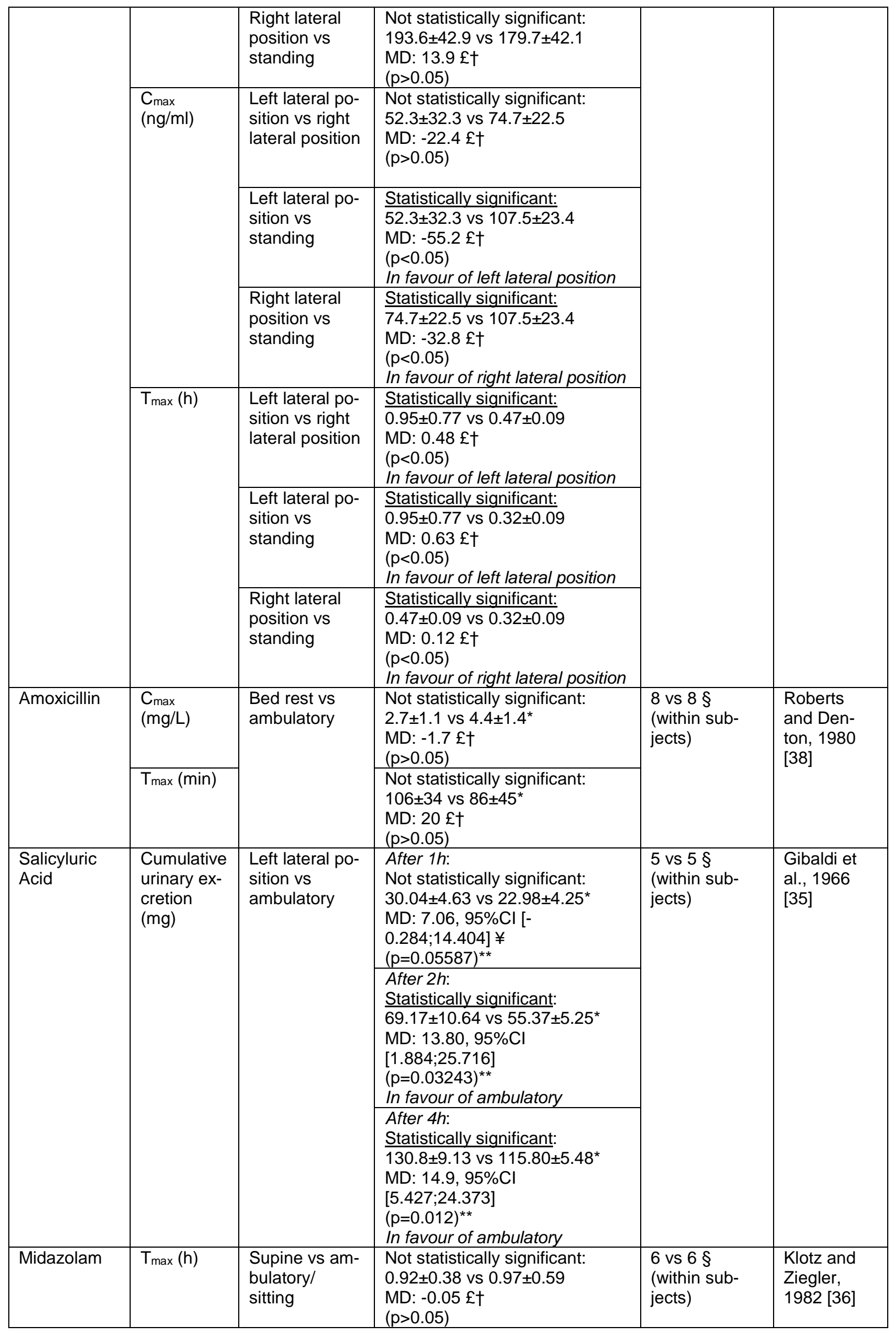




\begin{tabular}{|c|c|c|c|c|c|}
\hline & $\begin{array}{l}\mathrm{C}_{\max } \\
(\mathrm{ng} / \mathrm{ml})\end{array}$ & & $\begin{array}{l}\text { Statistically significant: } \\
74 \pm 39 \text { vs } 132 \pm 57 \\
\text { MD: }-58,95 \% \mathrm{Cl}[-90.621 ;- \\
25.378]^{\star *} \\
(\mathrm{p}=0.006) \\
\text { In favour of supine }\end{array}$ & & \\
\hline \multirow[t]{9}{*}{ Nitropyridine } & \multirow[t]{3}{*}{$\begin{array}{l}\operatorname{AUC}_{(0-24 h)} \\
((\mathrm{ng} / \mathrm{ml}) \mathrm{X} \\
\mathrm{h})\end{array}$} & $\begin{array}{l}\text { Left lateral po- } \\
\text { sition vs right } \\
\text { lateral position }\end{array}$ & $\begin{array}{l}\text { Not statistically significant: } \\
185.6 \pm 45.8 \text { vs } 193.6 \pm 42.9 \\
\text { MD: }-8.0 £ \dagger \\
(p>0.05)\end{array}$ & & \\
\hline & & $\begin{array}{l}\text { Left lateral po- } \\
\text { sition vs } \\
\text { standing }\end{array}$ & $\begin{array}{l}\text { Not statistically significant: } \\
185.6 \pm 45.8 \text { vs } 179.7 \pm 42.1 \\
\text { MD: } 5.9 £ \dagger \\
(p>0.05)\end{array}$ & & \\
\hline & & $\begin{array}{l}\text { Right lateral } \\
\text { position vs } \\
\text { standing }\end{array}$ & $\begin{array}{l}\text { Not statistically significant: } \\
193.6 \pm 42.9 \text { vs } 179.7 \pm 42.1 \\
\text { MD: } 13.9 £ \dagger \\
(p>0.05)\end{array}$ & & \\
\hline & \multirow[t]{3}{*}{$\begin{array}{l}\mathrm{C}_{\max } \\
(\mathrm{ng} / \mathrm{ml})\end{array}$} & $\begin{array}{l}\text { Left lateral po- } \\
\text { sition vs right } \\
\text { lateral position }\end{array}$ & $\begin{array}{l}\text { Not statistically significant: } \\
52.3 \pm 32.3 \text { vs } 74.7 \pm 22.5 \\
\text { MD: }-22.4 £ \dagger \\
(p>0.05)\end{array}$ & & \\
\hline & & $\begin{array}{l}\text { Left lateral po- } \\
\text { sition vs } \\
\text { standing }\end{array}$ & $\begin{array}{l}\text { Statistically significant: } \\
52.3 \pm 32.3 \text { vs } 107.5 \pm 23.4 \\
\text { MD: }-55.2 £ \dagger \\
\text { ( } p<0.05 \text { ) } \\
\text { In favour of left lateral position }\end{array}$ & & \\
\hline & & $\begin{array}{l}\text { Right lateral } \\
\text { position vs } \\
\text { standing }\end{array}$ & $\begin{array}{l}\text { Statistically significant: } \\
74.7 \pm 22.5 \text { vs } 107.5 \pm 23.4 \\
\text { MD: }-32.8 £ \dagger \\
(p<0.05) \\
\text { In favour of right lateral position }\end{array}$ & & \\
\hline & \multirow[t]{3}{*}{$T_{\max }(\mathrm{h})$} & $\begin{array}{l}\text { Left lateral po- } \\
\text { sition vs right } \\
\text { lateral position }\end{array}$ & $\begin{array}{l}\text { Statistically significant: } \\
0.95 \pm 0.77 \text { vs } 0.47 \pm 0.09 \\
\text { MD: } 0.48 £ \dagger \\
(p<0.05) \\
\text { In favour of left lateral position }\end{array}$ & & \\
\hline & & $\begin{array}{l}\text { Left lateral po- } \\
\text { sition vs } \\
\text { standing }\end{array}$ & $\begin{array}{l}\text { Statistically significant: } \\
0.95 \pm 0.77 \text { vs } 0.32 \pm 0.09 \\
\text { MD: } 0.63 £ \dagger \\
(p<0.05) \\
\text { In favour of left lateral position }\end{array}$ & & \\
\hline & & $\begin{array}{l}\text { Right lateral } \\
\text { position vs } \\
\text { standing }\end{array}$ & $\begin{array}{l}\text { Statistically significant: } \\
0.47 \pm 0.09 \text { vs } 0.32 \pm 0.09 \\
\mathrm{MD}: 0.12 £ \dagger \\
(\mathrm{p}<0.05) \\
\text { In favour of right lateral position }\end{array}$ & & \\
\hline $\begin{array}{l}\text { Slow-release } \\
\text { theophylline }\end{array}$ & $\begin{array}{l}\text { Adverse } \\
\text { events }\end{array}$ & $\begin{array}{l}\text { Supine posi- } \\
\text { tion vs } \\
\text { standing }\end{array}$ & $\begin{array}{l}\text { Not statistically significant: } \\
0 / 6 \text { vs } 0 / 6 \S \\
\text { RR not estimable }\end{array}$ & $\begin{array}{l}6 \text { vs } 6 \text { (within } \\
\text { subjects) }\end{array}$ & $\begin{array}{l}\text { Warren and } \\
\text { Barnes, } \\
1985 \text { [39] }\end{array}$ \\
\hline
\end{tabular}

Mean \pm SD, MD: mean difference, SD: standard deviation, $\mathrm{Cl}$ : confidence interval

* Mean values and SD calculated in Excel

** $\mathrm{Cl}$ and $\mathrm{p}$-value calculated in $\mathrm{R}$ with paired t-test

£ No Cl's available

££ No data available

$\S$ Imprecision (limited sample size/low number of events)

$¥$ Imprecision (large variability of results)

† Imprecision (lack of data) 
